\title{
ANALISIS KESESUAIAN DAN DAYA DUKUNG EKOSISTEM TERUMBU KARANG SEBAGAI EKOWISATA BAHARI DI PULAU DODOLA KABUPATEN PULAU MOROTAI
}

\author{
Kismanto Koroy, Nurafni, Muamar Mustafa \\ Program Studi IImu Kelautan, Fakultas Perikanan dan IImu Kelautan, \\ Universitas Pasifik Morotai \\ E-mail:kismantokoroy@gmail.com
}

Received March 2018, Accepted April 2018

\begin{abstract}
ABSTRAK
Ekosistem terumbu karang merupakan salah satu sumberdaya potensial wilayah pesisir dan pulau-pulau kecil yang memiliki nilai ekonomi dan ekologi. Pemanfaatan ekosistem terumbu karang untuk suatu kawasan wisata tanpa mempertimbangkan kapasitas daya dukung lingkungan dapat mendorong penurunan fungsi terumbu karang secara kompleks. Tujuan penelitian ini adalah mengetahui persentase tutupan terumbu karang yang ada di Pulau Dodola, mengetahui indeks kesesuaian wisata dan daya dukung kawasan di Pulau Dodola untuk kegiatan wisata bahari kategori wisata diving. Penelitian ini dilakukan pada bulan Agustus 2017 sampai bulan Januari 2018. Metode yang digunakan yaitu: Line Intercept Transect (LIT) dan Underwater Visual Census (UVC). Sedangkan kesesuaian dan daya dukung kawasan (DDK) diketahui dengan menggunakan analisis kesesuaian dan daya dukung kawasan. Hasil penelitian menunjukan, persentase nilai tutupan karang hidup Pulau Dodola berada pada kategori sangat baik dengan persentase nilai ratarata tutupan karang hidup dari ketiga stasiun pengamatan sebesar $85 \%$. Indeks kesesuaian wisata (IKW) untuk jenis wisata diving Pulau Dodola berada pada kategori kelas S1 dan S2. Kategori kelas S1 terdapat pada stasiun II dengan persentase nilai IKW sebesar $83.3 \%$ sementara kategori kelas S2 terdapat pada stasiun I dan III dengan persentase nilai IKW hanya mencapai $70.4 \%$ dan $81.5 \%$. Daya dukung kawasan (DDK) Pulau Dodola untuk jenis wisata diving memiliki kapasitas daya tampung pengunjung sebesar 153 orang per hari.
\end{abstract}

Kata kunci : Ekowisata, Terumbu Karang, Kesesuaian, Daya Dukung

\section{ABSTRACT}

Coral reef ecosystems are one of the potential resources of coastal areas and small island that have economic and ecological value. Utilization of coral reef ecosystems for a tourist area without considering the capacity of 
environmental carrying capacity can lead to a complex decline in coral reef function. The aims of this research is to the percentage of live coral cover at Dodola Island, to the tourist suitability index and the carrying capcity of the area in Dodola Island. This study was conducted in August 2017 Januari 2018. The method used in this research is Line Intercept Transect (LIT). 2) and Underwater Visual Census (UVC). The suitability and carrying capacity of the area is known by using conformity analyze and carrying capacity of the area. The result shows that the percentage of live coral cover value in Dodola Island is in very good category with the average percentage of live coral cover from three observation stations of $85 \%$. The tourist suitability index for this type in Dodola Island diving tourism is the category of class SI and S2. The Class category S1 is located on stations I and III with the percentage of tourist suitability index (TSI) value reaching only $70.4 \%$ and $81.5 \%$. The carrying capacity area (TCCA) of Dodola Island for the type of diving tourism has a visitor capacity of 153 people/ day.

Keywords : Ecotourism, Coral Reef, Conformity, Carrying Capacity

\section{PENDAHULUAN}

Kabupaten Pulau Morotai merupakan wilayah paling utara di Kawasan Timur Indonesia (KTI) yang termasuk bagian dari Provinsi Maluku Utara. Luas wilayah Pulau Morotai mencapai $2.314,90 \mathrm{~km}^{2}$ (BPS Kabupaten Pulau Morotai, 2017). Selain itu Pulau Morotai merupakan pulau terluar yang berbatasan langsung dengan negara tetangga dan memiliki fungsi strategis. Kabupaten Pulau Morotai dikelilingi sekitar 33 pulau-pulau kecil yang memiliki potensi sumberdaya perikanan dan pariwisata yang dapat dimanfaatkan sebagai kawasan ekowisata (Dinas Pariwisata Kabupaten Pulau Morotai, 2015).

Ekowisata bahari diartikan sebagai suatu konsep pemanfaatan sumberdaya alam pesisir yang berkelanjutan dengan sistem pelayanan jasa lingkungan yang mengutamakan sumberdaya alam pesisir sebagai objeknya (Yulianda et al. 2007). Selain memiliki nilai historis pulau-pulau kecil yang terdapat di Pulau Morotai juga memiliki keindahan serta keunikan yang menjadi daya tarik tersendiri. Salah satunya adalah Pulau Dodola. Pulau Dodola merupakan salah satu kawasan wisata bahari yang memiliki keindahan dan keunikan tersendiri serta kekayaan sumberdaya alam potensial seperti ekosistem terumbu karang (coral reef ecosystem) yang dapat dijadikan sebagai aset untuk dikembangkan di bidang kelautan dan perikanan. Pemanfaatan kawasan wisata tanpa mempertimbangkan kapasitas daya dukung lingkungan dapat mendorong lajunya kerusakan terumbu karang yang dapat berdampak pada lingkungan dan ekosistem lainnya. Untuk meminimalisir kerusakan terumbu karang yang terjadi dibutuhkan data dan informasi serta perlindungan terhadap ekosistem terumbu karang melalui penelitian-penelitian ilmiah dengan mengetahui persentase tutupan terumbu karang dan indeks kesesuaian wisata serta 
daya dukung kawasan di Pulau Dodola untuk kegiatan wisata bahari (kategori diving).

\section{MATERI DAN METODE}

Penelitian ini dilaksanakan pada bulan Agustus 2017 sampai pada bulan Januari 2018, berlokasi di Pulau Dodola, Kecamatan Morotai Selatan Kabupaten Pulau Morotai. Berikut gambar peta lokasi penelitian.

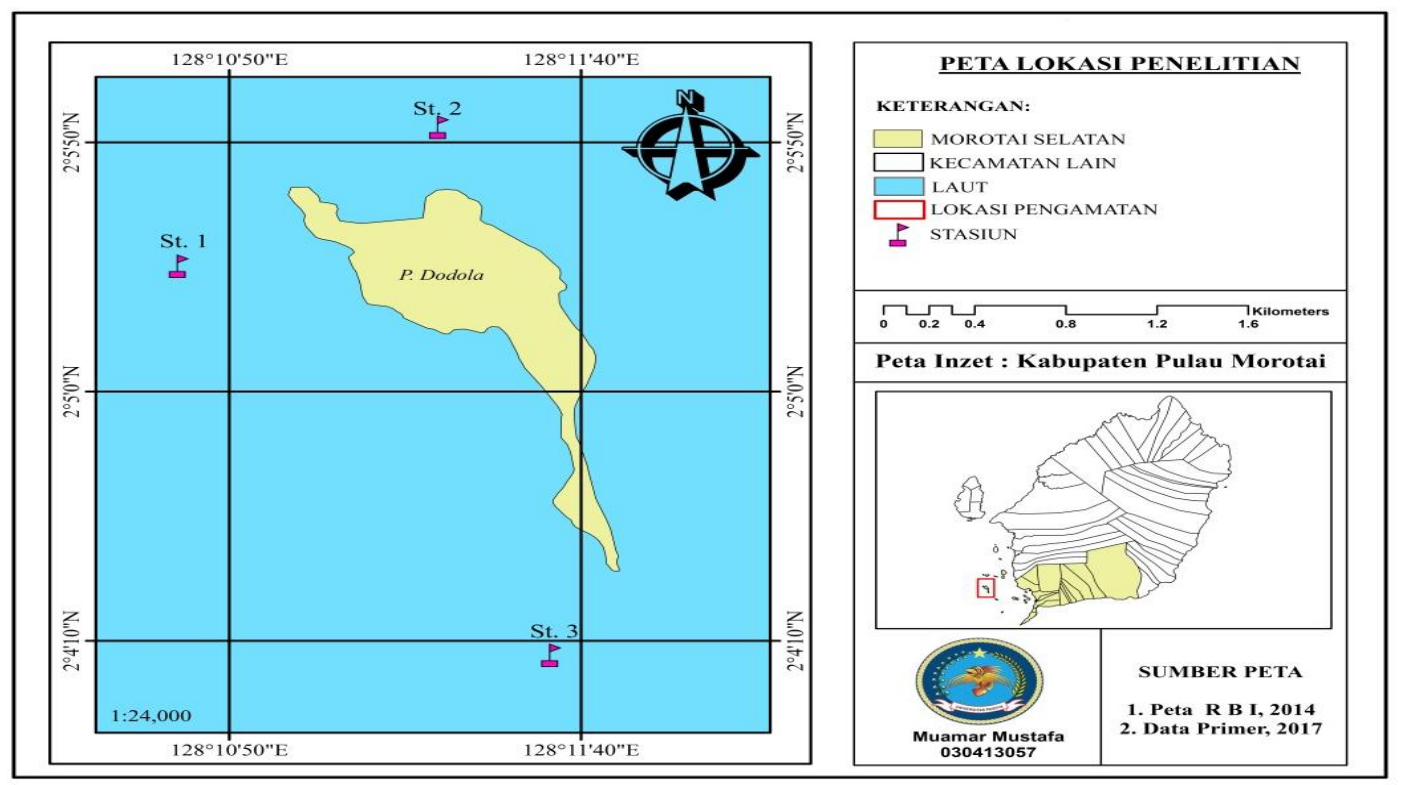

Gambar 1. Peta Lokasi Penelitian

Penentuan lokasi penelitian berdasarkan pertimbangan bahwa Pulau Dodola merupakan pulau wisata unggulan yang memiliki potensi sumberdaya pesisir dan laut sebagai objek dan daya tarik wisata (ODTW) seperti terumbu karang dan ikan karang, air laut yang jernih dan tipe pantai pasir putih yang dapat dimanfaatkan untuk kegiatan wisata. Pengambilan data biofisik dilakukan pada 3 stasiun. Penentuan stasiun pengamatan dilakukan secara sengaja (purposive sampling) dengan mempertimbangkan faktor fisik dan biologis sumber daya pesisir dan laut sebagai keterwakilan kawasan secara menyeluruh sesuai dengan tujuan penelitian. Selain itu metode pengambilan data terumbu karang menggunakan metode Line Intercept Transec (LIT) (English et al. 1997) dan pengukuran parameter perairan diperoleh langsung pada saat pengambilan data terumbu karang di tiap-tiap stasiun pengamatan. Alat dan bahan yang digunakan scuba, meteran rol, kamera, alat tulis, perahu, GPS, refraktometer, Secchi Disc, thermometer, pH meter, dan bola dan tali plastik. 


\section{Prosedur pengambilan data}

Survey lokasi dilakukan beberapa hari sebelum kegiatan penelitian berlangsung dengan melihat daerah yang dianggap sesuai dan menentukan tiap-tiap stasiun pengamatan terumbu karang dengan menentukan titik-titik koordinat dengan Global Positioning system (GPS). Pengambilan data karang dilakukan dengan teknik kategori lifeform (English et al. 1997), dengan menentukan 3 lokasi pengamatan terumbu karang, masing-masing lokasi ditentukan 1 titik untuk dijadikan stasiun peletakan transek dengan metode LIT (Line Intercept Transec). Peletakan transek dilakukan pada kedalaman yang disesuaikan dengan topografi perairan terumbu karang. Pengumpulan data dari tiap-tiap stasiun dilakukan dengan menarik garis transek sepanjang 50 meter sejajar dengan garis pantai. Pengumpulan data dilakukan dengan memotret terumbu karang (Underwater Photo Transek) yang dilintasi oleh tali transek pada tiap-tiap stasiun dengan kedalaman tertentu. Pengambilan data ikan karang menggunakan metode Underwater Visual Census (UVC) dimana ikan-ikan karang yang dijumpai pada jarak 2.5 meter dari sisi kiri maupun kanan garis transek sepanjang $50 \mathrm{~m}$ dicatat jenis dan jumlahnya. Sesuai luas bidang yang teramati per transeknya yaitu $\left(3 \times 50 \mathrm{~m}^{2}\right)=150$ $\mathrm{m}^{2}$ (Engish et al. 1997). Sedangkan pengukuran parameter di ambil pada tiap-tiap stasiun pengamatan yang meliputi: Suhu, Salinitas, Kedalaman, Arus permukaan, Kecerahan perairan, pH dan, Substrat dasar perairan.

\section{Analisis Data}

\section{Analisis Persentase tutupan karang}

Persentase tutupan karang Data persentase tutupan karang yang diperoleh berdasarkan metode LIT yang mengacu pada English et al. (1997) dihitung dengan persamaan sebagai berikut:

$$
\mathrm{Ni}=\frac{\mathrm{li}}{\mathrm{L}} \times 100 \%
$$

Keterangan: $\quad \mathrm{Ni}=$ Persentase penutupan karang

$\mathrm{Li}=$ Panjang total lifeform / jenis $\mathrm{ke}-\mathrm{i}$

$\mathrm{L} \quad=$ Panjang total transek $(50 \mathrm{~m})$

\section{Indeks kesesuaian wisata}

Untuk menentukan indeks kesesuaian pemanfaatan untuk wisata diving diformulasikan sebagai berikut (Yulianda, 2007):

$$
\mathrm{IKW}=\Sigma\left[\frac{\mathrm{Ni}}{\mathrm{Nmaks}}\right] \times 100 \%
$$


Keterangan: IKW = Indeks Kesesuaian Wisata

$\mathrm{Ni}=$ Nilai Parameter ke-i (Bobot $\mathrm{x}$ Skor)

$\mathrm{N}_{\text {maks }}=$ Nilai Maksimum dari suatu kategori wisata

Ketentuan untuk kelas kesesuaian kegiatan wisata diving adalah sebagai berikut:

$$
\begin{aligned}
& \text { S1 = Sangat sesuai, dengan IKW } 83-100 \% \\
& \text { S2 = Sesuai, dengan IKW } 50-<83 \% \\
& \text { S3 = Tidak sesuai, dengan IKW }<50 \%
\end{aligned}
$$

\section{Analisis daya dukung (DDK)}

Daya dukung kawasan (DDK) adalah jumlah maksimum pengunjung yang secara fisik dapat ditampung oleh kawasan yang disediakan pada waktu tertentu tanpa menimbulkan gangguan pada alam dan manusia, dapat dilihat pada rumus berikut:

$$
D D K=\mathrm{Kx}\left[\frac{\mathrm{Lp}}{\mathrm{Lt}}\right] \times\left[\frac{\mathrm{Wt}}{\mathrm{Wp}}\right]
$$

$$
\text { Keterangan: } \begin{aligned}
\mathrm{DDK}= & \text { Daya dukung kawasan } \\
\mathrm{K}= & \text { Potensi ekologis pengunjung per satuan unit area } \\
\mathrm{Lp}= & \text { Luas area atau panjang area yang dapat } \\
& \text { dimanfaatkan } \\
\mathrm{Lt}= & \text { Unit area untuk kategori tertentu } \\
\mathrm{Wt}= & \text { Waktu yang disediakan oleh kawasan untuk } \\
& \text { kegiatan wisata dalam satu hari } \\
\mathrm{Wp}= & \text { Waktu yang dihabiskan oleh pengunjung untuk } \\
& \text { setiap kegiatan tertentu }
\end{aligned}
$$

\section{HASIL DAN PEMBAHASAN}

\section{Gambaran Umum Lokasi Penelitian}

Pulau Morotai merupakan bagian dari Provinsi Maluku Utara dengan luas wilayah $\pm 2.314,90 \mathrm{Km}^{2}$. Letak geografis Pulau Morotai berada pada posisi $128^{\circ} 8^{\prime} 0^{\prime \prime}$ - $128^{\circ} 15^{\prime}$ - $129^{\circ} 08^{\prime}$ BT dan $2^{\circ} 00^{\prime}$ - $2^{\circ} 40^{\prime} \mathrm{LU}$ dengan batas wilayah antara lain (BPS Kabupaten Pulau Morotai, 2017). Secara administratif, bagian utara berbatasan dengan samudera pasifik, bagian timur berbatasan dengan laut halmahera, bagian selatan berbatasan dengan selat morotai dan bagian barat berbatasan dengan laut Halmahera.

Pulau Morotai memiliki \pm 33 pulau-pulau kecil yang mengililingi Pulau Morotai, 7 pulau diantaranya berpenghuni dan 26 pulau tidak berpenghuni, salah satunya adalah Pulau Dodola. Pulau Dodola 
merupakan salah satu kawasan wisata bahari yang termasuk dalam 10 destinasi wisata berdasarkan surat Sekretariat Kabinet No B 652/ SESKAB/ MARITIM/ 2015 (KEPMEN Perhubungan Republik Indonesia, 2016).

\section{Parameter Lingkungan Pulau Dodola}

Parameter lingkungan perairan Pulau Dodola yang diamati adalah parameter yang mempengaruhi perkembangan terumbu karang seperti suhu, salinitas, kecerahan perairan, $\mathrm{pH}$, kecepatan arus, kedalaman, dan substrat dasar perairan. Berdasarkan hasil pengukuran di lapangan menunjukkan parameter perairan terumbu karang di pulau Dodola masih dalam batas yang normal untuk mendukung pertumbuhan terumbu karang. Selanjutnya hasil pengukuran parameter perairan dapat dilihat pada Tabel 1 berikut:

Tabel 1. Parameter perairan Pulau Dodola

\begin{tabular}{lllll}
\hline No & Parameter & Stasiun & & \\
\hline & & $\mathrm{l}$ & $\mathrm{II}$ & $\mathrm{III}$ \\
1 & Suhu $\left({ }^{\circ} \mathrm{C}\right)$ & 28 & 27 & 28 \\
2 & Salinitas $(\% \circ)$ & 35 & 34 & 35 \\
3 & Kecerahan $(\%)$ & 100 & 100 & 100 \\
4 & $\mathrm{pH}$ & 8.3 & 8.5 & 8.3 \\
5 & Arus $(\mathrm{m} / \mathrm{d})$ & 1.14 & 7.18 & 1.37 \\
6 & Kedalaman $(\mathrm{m})$ & 5.5 & 6 & 5 \\
7 & Substrat & Batu- & Pasir- & Pasir- \\
& & berpasir & berbatu & berbatu \\
\hline
\end{tabular}

\section{Komunitas Tutupan Terumbu Karang}

Tutupan karang merupakan salah satu indikator penting dalam menentukan kesesuaian wisata selam di suatu perairan. Secara konvensional kondisi terumbu karang dinilai berdasarkan tutupan dan keanekaragaman spesies karang, serta kelimpahan dan keanekaragaman ikan karang (English et al. 1997). Semakin tinggi nilai yang diperoleh dari suatu jenis tutupan komunitas karang maka semakin tinggi pula tingkat kesehatan dari terumbu karang setempat yang dapat menjamin kelansungan serta eksistensi ekosistem terumbu karang pada suatu perairan dengan berlangsungnya proses regenerasi secara alami (Subur, 2012). Persentase komunitas tutupan terumbu karang di Pulau Dodola dapat disajikan dalam bentuk grafik pada Gambar 2 berikut: 


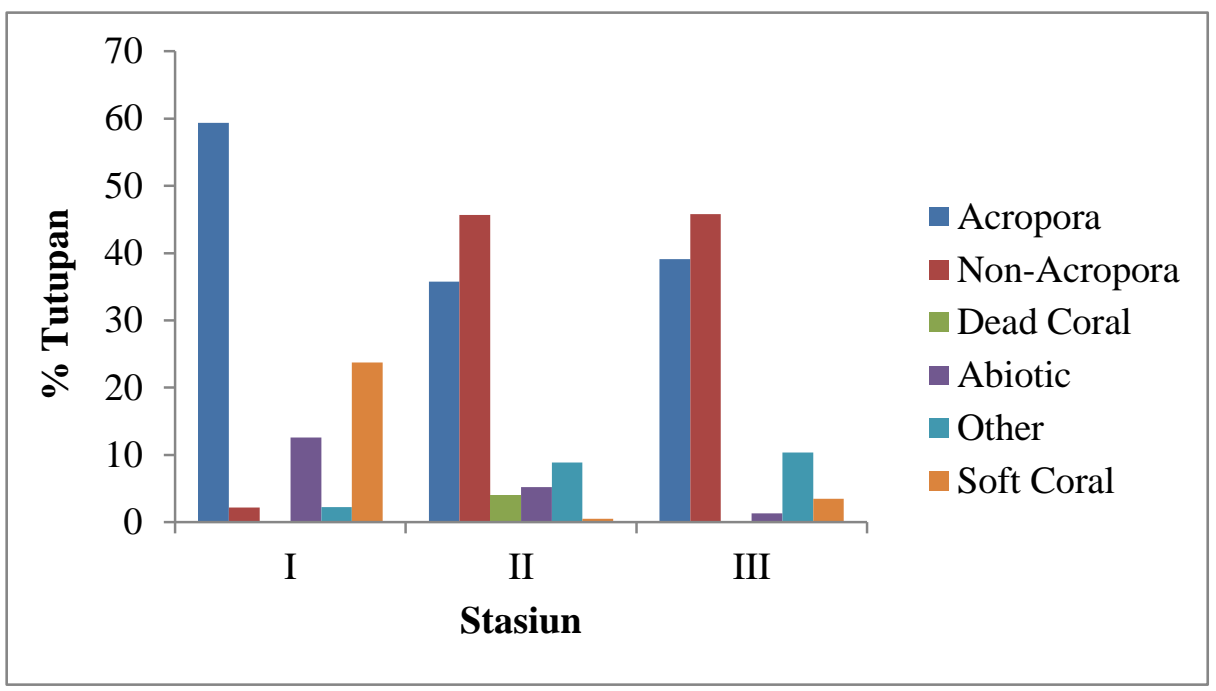

Gambar 2. Persentase Komunitas Tutupan Terumbu Karang Pulau Dodola

Persentase tutupan komunitas terumbu karang pada grafik di atas menunjukan dominasi tutupan tertinggi terumbu karang jenis Acropora hanya terlihat pada stasiun I dengan nilai $59 \%$, sedangkan pada stasiun II dan III lebih di dominasi oleh terumbu karang jenis non Acropora dengan nilai persentase masing-masing adalah 39 sampai $42 \%$, sedangkan komunitas tutupan terendah adalah jenis soft coral dengan nilai terendah pada stasiun II sebesar $2 \%$. Selain itu pada stasiun II ditemukan $4 \%$ dead coral, Namun secara keseluruhan persentase tutupan tertinggi dari ketiga stasiun lebih di dominasi oleh terumbu karang jenis Acropora. hal tersebut jelas terlihat karena jenis Acropora adalah jenis yang paling sering dijumpai di lokasi penelitian. Tingginya persentase tutupan karang jenis Acropora dapat disebabkan oleh faktor abiotik seperti substrat dasar perairan yang sesuai dan memungkinkan terumbu karang jenis Acropora untuk tumbuh. Pada daerah rataan terumbu dengan substrat dasar yang lunak jenis karang yang biasa dominan adalah jenis Acropora dan Montipora (Suharsono, 1998) dalam (Kordi, 2010). Parameter arus permukaan dapat berpengaruh terhadap tingkat dominasi tutupan karang lunak (soft coral), hal ini terlihat pada stasiun I (24\%), stasiun II ( $2 \%)$, dan stasiun III (6\%) dengan kisaran arus yang berbeda-beda, maka dapat di asumsikan bahwa arus perairan merupakan salah satu parameter yang membatasi dominasi karang lunak.

\section{Jenis Lifeform Karang}

Jenis lifeform atau bentuk pertumbuhan karang adalah salah satu parameter penting dalam penentuan kelas kesesuaian wisata selam, selain faktor genetik bentuk pertumbuhan koloni karang dapat dipengaruhi oleh kondisi lingkungan suatu perairan seperti intensitas cahaya, 
gelombang, arus, ketersediaan bahan makanan, sedimen dan subareal exposure (Syarifuddin, 2011).

Tabel 2. Jumlah jenis lifeform tiap-tiap stasiun

\begin{tabular}{lll}
\hline Stasiun & Jenis Lifeform & Jumlah \\
\hline I & ACB, CF, SC, CMR, CM & 5 \\
II & ACB, CF, CM, ACS, CMR, SC, ACT, CB, ACD, & 10 \\
& DCA & 8 \\
\hline
\end{tabular}

Jenis dan jumlah lifeform yang ditemukan pada stasiun I hanya terdiri dari Acropora branching (ACB), Coral foliose (CF), Soft coral (SC), Coral mushroom (CMR), dan Coral massive (CM). Pada stasiun II menunjukan variasi dengan 10 jenis, diantaranya adalah Acropora branching (ACB), Coral faliose (CF), Coral massive (CM), Acropora submassive (ACS), Coral mushroom (CMR), Soft coral (SC), Acropora tabulate (ACT), Coral branching (CB), dan Acropora digitate (ACD), serta karang mati yang ditutupi alga (DCA). Sedangkan pada stasiun III ditemukan sedikitnya 8 jenis lifeform seperti Coral massive (CM), Coral branching (CB), Acropora digitate (ACD), Acropora branching (ACB), Soft coral (SC), Acropora submassive (ACS), Coral faliose (CF) dan jenis Coral mushroom (CMR). Kehadiran beberapa kategori lifeform yang dominan seperti Acropora branching (ACB) dan Coral masif (CM) pada masingmasing stasiun ditunjang dengan kondisi substrat dasar perairan yang cukup sesuai. Jenis karang ACB, CB dan CM adalah kategori karang yang cocok pada tipe substrat yang keras dan arus yang beragam (Pangabean, 2012).

\section{Jenis Ikan Karang}

Selain keberadaan terumbu karang yang menjadi parameter penting kesesuaian wisata selam, jenis ikan karang juga menjadi penting untuk diamati. Kehadiran ikan karang merupakan objek dalam kegiatan wisata selam yang harus diperhitungkan. Hasil pengamatan pada ketiga titik penyelaman menunjukan adanya perbedaan sebaran ikan karang pada masing-masing stasiun. Sebaran ikan karang yang ditemukan pada stasiun I hanya berjumlah 9 jenis, stasiun II memiliki nilai sebaran jenis kategori sedang dengan jumlah 20 jenis ikan karang, sementara pada stasiun III memiliki tingkat sebaran tertinggi diantara stasiun I dan II dengan jumlah 26 jenis ikan karang. Jumlah jenis yang ditemukan secara keseluruhan berjumlah 55 jenis, namun jumlah tersebut sudah termasuk jumlah kehadiran beberapa jenis yang sama yang juga dijumpai pada tiaptiap stasiun, sedangkan jumlah bersih keterwakilan pada masing-masing stasiun secara keseluruhan berjumlah 43 jenis. Berdasarkan data tersebut dapat dijelaskan bahwa rendahnya jumlah jenis ikan karang yang 
ditemukan pada stasiun I berkaitan dengan rendahnya variasi tutupan karang hidup dan bentuk lifeform karang pada stasiun I. Artinya, semakin tinggi variasi tutupan karang hidup maka semakin tinggi pula variasi sebaran ikan karang yang menjadikan terumbu karang sebagai habitatnya. Kasus serupa juga dilaporkan Atjo et al. (2010), bahwa hasil analisis menunjukan tingginya persentase tutupan karang hidup dan rugositas terumbu karang pada salah satu stasiun di Pulau Barang lompo sebanding dengan tingginya kelimpahan ikan karang pada stasuin tersebut, begitupun sebaliknya. Menurut Nybakken (1988), bahwa variasi habitat yang terdapat pada terumbu karang merupakan salah satu penyebab tingginya keragaman spesies ikan karang

\section{Indeks Kesesuaian Ekowisata Bahari Kategori Diving Pulau Dodola}

Pengukuran data lapangan untuk masing-masing parameter pada tiap-tiap stasiun pengamatan selanjutnya dilakukan proses perhitungan dengan pendekatan beberapa teori yang kemudian disajikan dalam bentuk grafik pada Gambar 3 berikut:

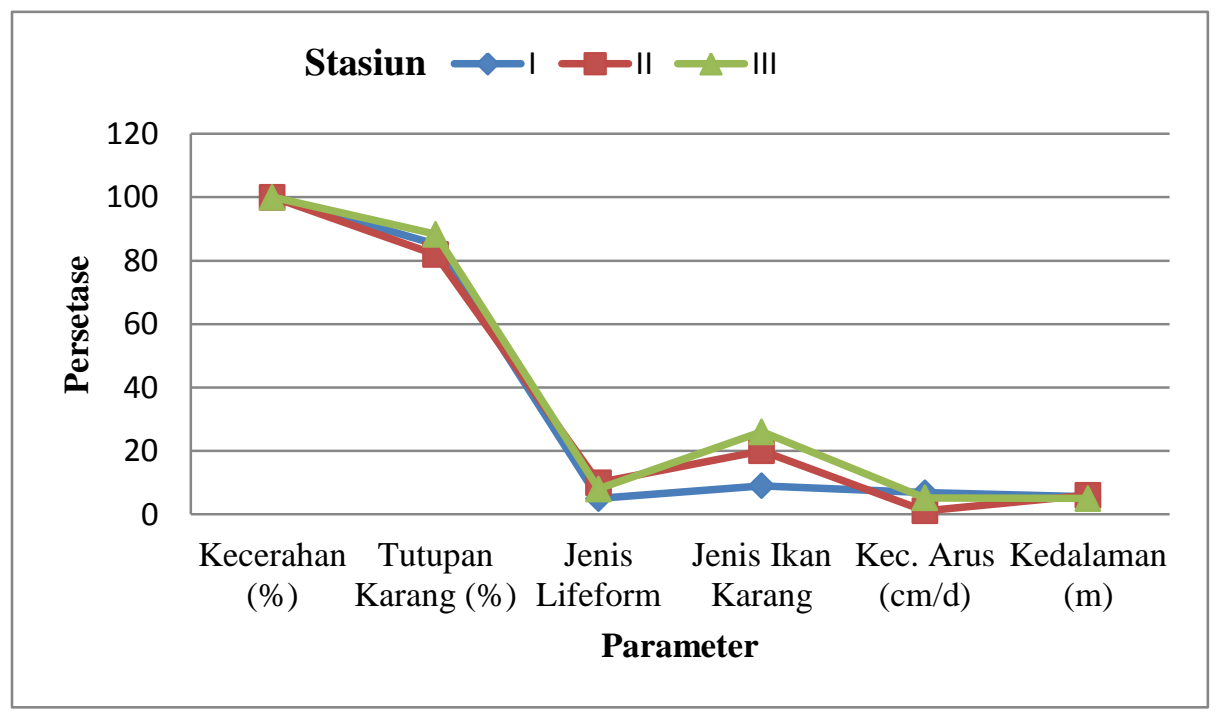

Gambar 3. Grafik persetase nilai parameter kesesuaian tiap-tiap stasiun

Nilai parameter untuk penentuan kesesuaian seperti kecerahan perairan, persentase tutupan karang hidup, kecepatan arus dan, parameter kedalaman dari ketiga stasiun di atas secara keseluruhan tidak memberikan perbedaan yang berarti meskipun pada parameter tutupan karang hidup dan parameter kecepatan arus dari ketiga stasiun memberikan angka persentase dan nilai standar yang sedikit berbeda. Namun, perolehan skor penilaian untuk parameter tutupan karang hidup serta kecepatan arus dari ketiga stasiun tersebut adalah sama, sehingga tidak memberikan pengaruh yang cukup signifikan. Sebaliknya perbedaan jumlah jenis jelas terlihat pada parameter jumlah jenis lifeform dan jenis ikan karang. Dimana, persentase nilai jenis lifeform dan ikan karang pada 
masing-masing stasiun terlihat berbeda (Gambar 3), hal ini jelas memberikan pengaruh terhadap perolehan skor penilaian yang nantinya akan menentukan perbedaan kelas kesesuaian pada masing-masing stasiun.

Penentuan kelas kesesuaian kawasan terumbu karang untuk pemanfaatan ekowisata bahari jenis kagiatan diving secara teknis mengacu pada analisis kesesuaian ekowisata bahari menurut Yulianda (2007). Berdasarkan hasil analisis yang diperoleh dari nilai masing-masing parameter kesesuaian pada tiap-tiap stasiun, maka diperoleh persentase angka yang dapat menentukan kelas kesesuaian ekowisata bahari jenis kegiatan diving tersebut. Kategori kelas kesesuaian masing-masing stasiun dapat disajikan dalam bentuk tabel berikut:

Tabel 3. Indeks kesesuaian wisata diving pada masing-masing stasiun

\begin{tabular}{lllll}
\hline Stasiun & Latitude & Longitude & $\begin{array}{l}\text { Indeks } \\
\text { Kesesuaian } \\
\text { Wisata (IKW) }\end{array}$ & Keterangan \\
\hline I & $02^{\circ} 05^{\prime} 12.37^{\prime \prime}$ & $128^{\circ} 49^{\prime} 34.44^{\prime \prime}$ & & \\
& $N$ & $E$ & 70.4 & $\begin{array}{l}\text { Sesuai (S2) } \\
\text { Sangat Sesuai } \\
\text { II }\end{array}$ \\
$02^{\circ} 04^{\prime} 17.12^{\prime \prime}$ & $128^{\circ} 49^{\prime} 34.44^{\prime \prime}$ & & $(\mathrm{S} 1)$ \\
& $\mathrm{N}$ & $\mathrm{E}$ & 83.3 & \\
III & $02^{\circ} 05^{\prime} 7.16^{\prime \prime}$ & $128^{\circ} 11^{\prime} 5.45^{\prime \prime}$ & & Sesuai (S2) \\
\hline
\end{tabular}

Hasil analisis menunjukan kategori kelas kesesuaian yang diperoleh dari ketiga stasiun tersebut diatas berada pada kategori kelas S1 dan S2, dimana Indeks kesesuaian wisata (IKW) jenis kegiatan wisata diving yang diperoleh pada stasiun I dan III yang masuk dalam kategori kelas S2 dengan nilai persentase 70.4 dan $81.5 \%$, sementara pada stasiun II memiliki nilai persentase yang cukup tinggi yaitu $83.3 \%$ dengan kategori kelas S1. Berdasarkan parameter yang berfokus pada jenis lifeform dan jumlah jenis ikan karang ketiga stasiun yang ditemukan memperlihatkan adanya sedikit perbedaan. Dimana, perolehan jumlah lifeform dan jenis ikan karang pada stasiun I dan III seperti yang telah dijelaskan sebelumnya bahwa, perbedaan kategori kelas kesesuaian antara stasiun I, III serta stasiun II dipengaruhi oleh perolehan skor dari parameter jenis lifeform dan jumlah jenis ikan karang, meskipun jumlah jenis dari kedua parameter tersebut hanya memberikan sedikit perbedaan dalam hal jumlah namun cukup memberikan pengaruh terhadap persentase nilai untuk penentuan kelas kesesuaian. Kesesuaian lokasi pemanfaatan terumbu karang untuk kegiatan ekowisata kategori wisata diving Pulau Dodola dapat dilihat pada gambar berikut: 


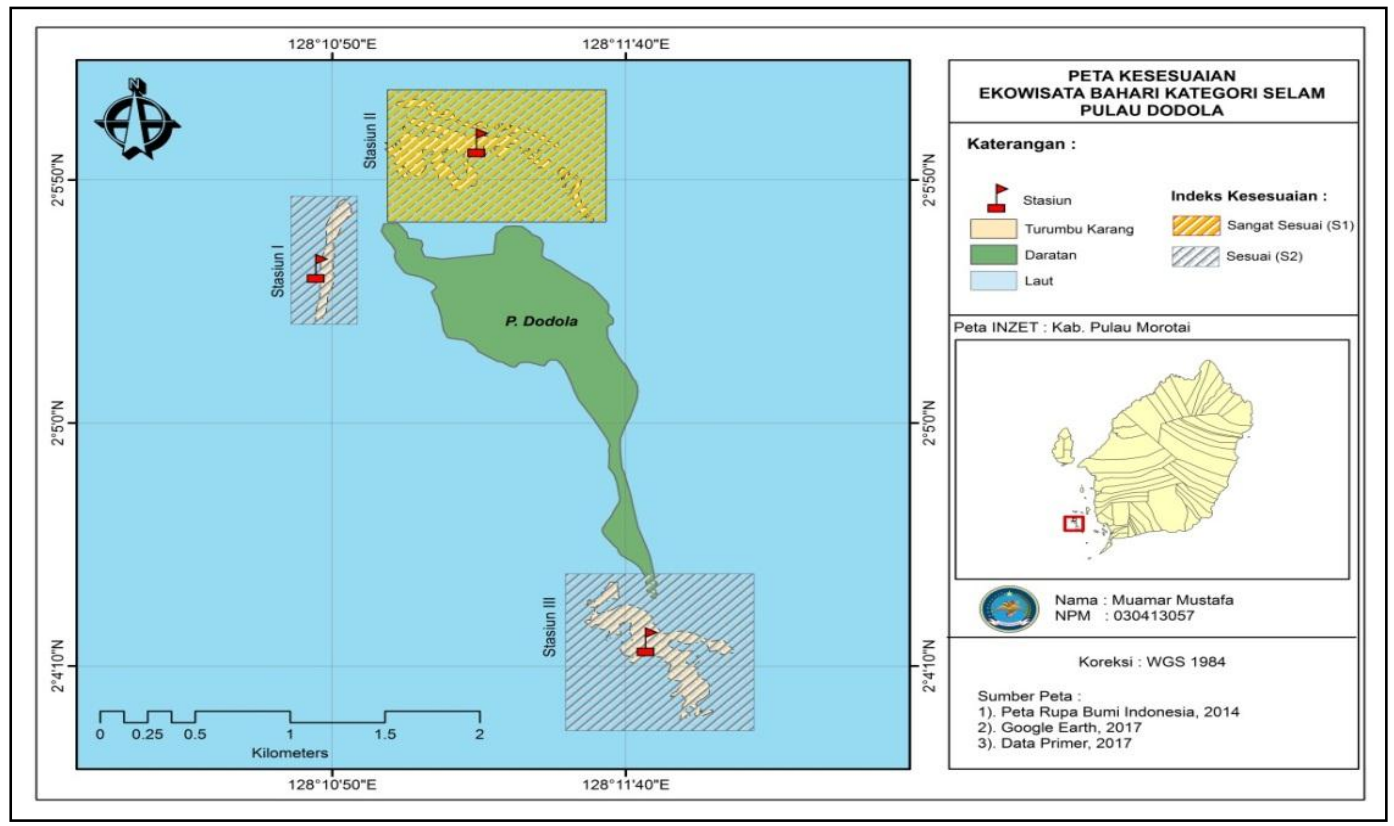

Gambar 4. Peta kesesuaian ekowisata kategori wisata diving

Hasil analisis Nilai pesentase indeks kesesuaian wisata selam Pulau Dodola stasiun I dan III yakni 70.4 - 81.5\% berada pada kategori kelas yang sama yaitu S2 (sesuai), sementara stasiun II dengan nilai 83.3\% masuk pada kategori kelas S1 (sangat sesuai). Hal ini menunjukan bahwa faktor-faktor pembatas seperti kecerahan perairan, persentase tutupan karang, jenis lifeform, jenis ikan karang, kecepatan arus dan kedalaman merupakan faktor yang turut mempengaruhi penentuan kelas kesesuaian ekowisata khususnya wisata diving.

\section{Daya Dukung Kawasan Pulau Dodola}

Analisis daya dukung kawasan (DDK) merupakan suatu metode yang dapat meminimalisir tekanan yang diterima oleh lingkungan dari aktivitas pelaku wisata. Konsep daya dukung ekowisata bahari yang merujuk pada Yulianda (2007) kiranya mampu memberikan solusi untuk pengembangan kawasan ekowisata yang ada di Pulau Morotai khususnya Pulau Dodola kedepannya. Berdasarkan karakteristik sumberdaya dan peruntukannya, perhitungan daya dukung ekowisata bahari untuk wisata diving ditentukan berdasarkan sebaran dan kondisi terumbu karang yang ada di Pulau Dodola dengan mempertimbangkan potensi ekologis pengunjung, luas area dan prediksi waktu yang dibutuhkan untuk kategori kegiatan diving. Formulasi untuk menghitung daya dukung kawasan dengan pendekatan teori menurut Yulianda (2007) telah memiliki nilai ketetapan maksimal pada setiap parameter kecuali nilai parameter (Lp) luas area terumbu karang yang dapat dimanfaatkan (Tabel 4). 
Tabel 4. Daya dukung kawasan Pulau Dodola

\begin{tabular}{lllll}
\hline \multirow{2}{*}{ Jenis Kegiatan } & \multicolumn{2}{l}{ Stasiun } & & \multirow{2}{*}{ Jumlah } \\
\cline { 2 - 5 } & I & II & III & \\
\hline Diving & 19 & 68 & 66 & 153 \\
\hline
\end{tabular}

Hasil analisis menunjukan bahwa luas area terumbu karang Pulau Dodola yang dapat dimanfaatkan pada stasiun I adalah $47.351 \mathrm{~m}^{2}$, stasiun II $170.297 \mathrm{~m}^{2}$ dan, stasiun III sebesar $165.189 \mathrm{~m}^{2}$. Berdasarkan nilai yang diperoleh, maka dapat diketahui daya dukung kawasan (DDK) untuk wisata diving pada stasiun I berjumlah 19 orang, stasiun II sebanyak 68 orang dan, stasiun III sebanyak 66 orang. Sehingga secara keseluruhan daya dukung kawasan ketiga stasiun untuk aktivitas wisata selam hanya dibolehkan 153 orang per hari.

\section{KESIMPULAN}

Persentase nilai tutupan karang hidup Pulau Dodola berada pada kategori sangat baik dengan persentase nilai rata-rata tutupan karang hidup dari ketiga stasiun pengamatan sebesar $85 \%$ dan Indeks kesesuaian wisata (IKW) untuk jenis wisata diving di Pulau Dodola berada pada kategori kelas S1 dan S2. Kategori kelas S1 terdapat pada stasiun II dengan persentase nilai IKW sebesar $83.3 \%$ sementara kategori kelas S2 (sesuai) terdapat pada stasiun I dan III dengan persentase nilai IKW hanya mencapai $70.4 \%$ dan $81.5 \%$. Daya dukung kawasan (DDK) Pulau Dodola untuk jenis wisata diving memiliki kapasitas daya tampung pengunjung sebesar 153 orang per hari.

\section{DAFTAR PUSTAKA}

Atjo AA, Burhanuddin I A, Rani C. 2010. Sebaran dan Keragaman Ikan Karang di Pulau Barang lompo: Kaitannya Dengan Kondisi dan Kompleksitas Habitat. Jurusan IImu Kelautan, Fakultas IImu Kelautan Dan Perikanan. UNHAS Makassar.

[Badan Pusat Statistik Kabupaten Pulau Morotai, 2017]. Kabupaten Pulau Morotai Dalam Angka. BPS Kabupaten Pulau Morotai.

[Dinas Pariwisata Pulau Morotai Provinsi Maluku Utara, 2015]. Pulau Morotai. [Internet]. [Diunduh 2017 November, 08]. Pukul 05:50 WIT. Tersedia Pada : http://disbudpar.malutprov.go.id/wpcontent/uploads/2015/11/008-pulau-morotai.pdf 
English S, Wilkinson C, Baker V. 1997. Survey Manual for Tropical Marine Resources. ASEAN-Australia Marine Science Project : Living Coastal Resources. Australia Institute Of Marine Science. Townsville.

KEPMEN Perhubungan Republik Indonesia Nomor KP 901, 2016. Tentang Rencana Induk Pelabuhan Nasional.

Kordi KHGM. 2010. Ekosistem Terumbu Karang. Hal 3-85. Rineka Cipta 2010. Jakarta.

Nybakken, JW. 1988. Biologi Laut: Suatu Pendekatan Ekologi. PT. Gramedia, Jakarta.

Pangabean S Anthony. 2012. Keanekaragaman Jenis Ikan Karang Dan Kondisi Kesehatan Karang Di Pulau Gof Kecil Dan Yep Nabi Kepulauan Raja Ampat. Jurnal Lit. Perikanan Indonesia. 18:(2):109-115. Balai Penelitian Perikanan Laut. Muara Baru. Jakarta.

Subur R. 2012. Daya Dukung Ekowisata Dengan Pendekatan Kapasitas Adaptif Ekologi (Studi Kasus Gusus Pulau Guraici Kabupaten Halmahera Selatan Propinsi Maluku Utara). [Ringkasan Disertasi]. Institut Pertanian Bogor.

Suharsono BA. 2008. Jenis - jenis Karang di Indonesia. Indonesian Institut eof Science (LIPI). Pusat Penelitian Oseanografi. LIPI Press Jakarta.

Syarifuddin AA. 2011. Studi Kelangsungan Hidup Dan Pertumbuhan Karang Acropora Formosa (Veron \& Terrence, 1979) Menggunakan Teknologi Biorock Di Pulau Barrang Lompo Kota Makassar. [Skripsi]. Manajemen Sumberdaya Perairan. Universitas Hasanuddin Makassar.

[TIES] The International Ecoturism Society. 2015. What is Ecotourism. [internet] [diunduh 31 Aug 2015]; tersedia pada: https:// www. ecotourism. org /what -is-ecotourism.

Yulianda F. 2007. Ekowisata Bahari Sebagai Alternatif Pemanfaatan Sumberdaya Pesisir Berbasis Konservasi. Seminar Sains pada Departemen MSP, FPIK IPB. 21 Februari 2007; Bogor (ID): Departemen MSP IPB. 